\title{
INFLUENCE OF ALBUMIN ON GUAVA PULP POWDER OBTAINED BY FOAM-MAT DRYING
}

\author{
Roberta M. G. Maciel $^{1}$, Marcos R. A. Afonso ${ }^{1 *}$, José M. C. da Costa ${ }^{1}$, Tayla M. R. Araújo ${ }^{1}$ \\ ${ }^{1 *}$ Corresponding author. Federal University of Ceara/ Fortaleza - CE, Brazil. \\ E-mail: m.r.a.afonso@gmail.com |ORCID ID: https://orcid.org/0000-0002-8149-6276
}

\section{KEYWORDS}

tropical fruit, food powder, isotherm.

\begin{abstract}
Guava is a fruit that stands out for its aroma, intense flavor, vitamins, and minerals. Its availability as a powdered food enhances its commercial applications. This study aimed to evaluate mathematical models for adsorption isotherms and determine the properties and flowability of guava pulp powder obtained by foam-mat drying. The models of GAB, BET, Henderson and Oswin were fitted to determine the isotherms of powders with 4 and $8 \%$ albumin, at temperatures of $35^{\circ} \mathrm{C}$ and $45^{\circ} \mathrm{C}$. The powders were evaluated by wall friction angle, flow index, apparent density, and particle microstructure analysis. The best fit to the isotherms was obtained by the GAB model. Wall friction angle ranged from 15.7 to $21.9^{\circ}$ and from 13.6 to $20.4^{\circ}$ for samples containing 4 and $8 \%$ albumin, respectively. Higher densities were observed in the powder containing $8 \%$ albumin. The powders were classified as easy flowing when the flow index was between 8.00 and 8.68. The presence of albumin in powders resulted in particles with less rough surfaces, less hygroscopicity, and improved flowability.
\end{abstract}

\section{INTRODUCTION}

Guava (Psidium guajava L.) is an easy-to-grow tropical fruit tree in Brazilian territory and stands out due to high vitamin $\mathrm{C}$ content in its fruit. It also has high amounts of sugar, vitamin A, vitamin B, phosphorus, iron, and calcium (Silva et al., 2014). Guavas, like most fruits, are highly perishable and require processing to increase shelf life, transforming them into new products (Infante et al., 2013).

Drying methods enable processing of fruit into a powder, increasing product shelf-life and added value, allowing its use in a wide range of food formulations on an industrial scale (Mata et al., 2005). Powdered product storage conditions must be known to maintain product quality, such as better environmental and packaging conditions for protection from external influences (Sagar \& Kumar, 2014).

Food physical, chemical, and microbiological stability depend on its water content and availability, as well as its interaction with other food components. At constant temperature, food moisture content changes until it reaches equilibrium with the water vapor in the environment. One way to assess powder behavior in different environments is through sorption isotherms, at varied temperature and humidity (Matos et al., 2014). Adsorption of water by dehydrated foods is mainly caused by the chemical nature of its organic components, such as the presence of sugars, Van der Waals intermolecular forces, bonds between $\mathrm{OH}-$ hydroxyl groups and water molecules, and dehydration process type (Park et al., 2008).

Several mathematical models can be fitted to isotherms and determine monolayer water content, which is related to the beginning of a series of deterioration chemical reactions, representing the point of maximum energy expenditure during the drying process (Ferreira \& Pena, 2003).

Some physical properties are used as a reference for powder handling and processing (Brito et al., 2012). Such properties must be understood in industries where powders are used as a raw material or final product, as they can affect their behavior during storage, handling, and processing (Medeiros \& Lannes, 2010). Attraction forces between powder particles can favor and, in some cases, increase flowing problems (Lopes Neto et al., 2009a).

Given the above, this study aimed to evaluate the hygroscopic behavior and physical properties of guava pulp powders obtained by the foam-mat method.

\section{MATERIAL AND METHODS}

The drying processes used two albumin concentrations $\left(4\right.$ and $8 \%, \mathrm{~m} \mathrm{~m}^{-1}$ ) mixed with guava pulp,

\footnotetext{
${ }^{1}$ Federal University of Ceara/ Fortaleza - CE, Brazil.
} 
using a domestic food mixer for $5 \mathrm{~min}$ to form the foam. Then, the foam was spread on aluminum trays, which were placed in a natural convection tray dryer at an air temperature of $78^{\circ} \mathrm{C}$ for $330 \mathrm{~min}$. This drying time had been determined before dryings, and the mass of samples was monitored every 15 min until mass variation was less than $1 \%$.

The static gravimetric method described by Spiess \& Wolf (1987) was used to evaluate adsorption isotherms from the powders. The powder samples were placed in crucibles and inside 6 cells or chambers (closed environment), with different relative humidity produced by saline solutions $\left(\mathrm{CH}_{3} \mathrm{COOK} 21 \%, \mathrm{~K}_{2} \mathrm{CO}_{3} 44 \%\right.$, NaBr 58\%, $\mathrm{SnCl}_{2} 76 \%, \mathrm{KCl} 84 \%, \mathrm{BaCl}_{2} 90 \%$ ) according to Greenspan (1977). Next, the samples were stored in a B.O.D incubator until reaching the balance between powder and solution humidity. The balance was verified at 35 and $45{ }^{\circ} \mathrm{C}$, weighing crucibles on an analytical balance until mass variation was less than $1 \%$. The equilibrium moisture content $(\mathrm{Xe})$ was determined according to Equation 1.

After equilibrium, the water activity of samples was measured using an AquaLab water activity meter (BrasEq, Jarinu, Brazil). Mathematical models were fitted to equilibrium moisture content and water activity data, using the Statistica 10.0 software. The fitted models were the following: GAB, BET, Henderson, and Oswin (Table 1).

$$
\mathrm{X}_{\mathrm{e}}=\frac{\mathrm{m}_{\mathrm{a}}}{\mathrm{m}_{\mathrm{s}}} \cdot 100
$$

Where:

$$
\begin{aligned}
& \text { Xe - equilibrium moisture }\left(\mathrm{g} \mathrm{g}^{-1}\right) \\
& \mathrm{m}_{\mathrm{a}} \text { - sample water mass after equilibrium }(\mathrm{g}), \\
& \mathrm{m}_{\mathrm{s}}-\text { sample dry mass }(\mathrm{g}) .
\end{aligned}
$$

TABLE 1. Mathematical models to describe adsorption isotherms of guava pulp powders.

\begin{tabular}{cc}
\hline Model & Xe $=\frac{\text { Equation }}{\left(1-K \cdot a_{w}\right) \cdot\left(1-K \cdot a_{w}+C \cdot K \cdot a_{w}\right)}$ \\
BET & $X e=\frac{X m \cdot C \cdot a_{w}}{\left(1-a_{w}\right)}\left[\frac{1-(n+1) \cdot\left(a_{w}\right)^{n}+n \cdot\left(a_{w}\right)^{n+1}}{1-(1-C) \cdot a_{w}-C \cdot\left(a_{w}\right)^{n+1}}\right]$ \\
Henderson & $X e=\left[\frac{\ln \left(1-a_{w}\right)}{b^{\frac{1}{a}}}\right]^{\text {Oswin }}$ \\
Xe $=a \cdot\left[\frac{a_{w}}{1-a_{w}}\right]^{b}$
\end{tabular}

$\mathrm{a}_{\mathrm{w}}$ - water activity (dimensionless); $\mathrm{X}_{\mathrm{e}}$ - equilibrium moisture $\left(\mathrm{g} \mathrm{g}^{-1}, \mathrm{db}\right) ; \mathrm{n}$ - number of molecular layers; $\mathrm{X}_{\mathrm{m}}$ - molecular monolayer moisture content ( $\left.\mathrm{g} \mathrm{g}^{-1}\right) ; \mathrm{a}, \mathrm{b}$ - model fit constants; $\mathrm{C}, \mathrm{K}$ - sorption constants.

The models were evaluated according to coefficients of determination $\left(\mathrm{R}^{2}\right)$ and relative mean errors $(\mathrm{E})$, defined as the means of the relative difference between the experimental and predicted values, according to [eq. (2)] (Kurozawa et al., 2005):

$$
\mathrm{E}=\frac{100}{\mathrm{n}} \sum_{\mathrm{i}-1}^{\mathrm{n}} \frac{\left|\left(\mathrm{M}_{\mathrm{i}}-\mathrm{Mp}_{\mathrm{i}}\right)\right|}{\mathrm{M}_{\mathrm{i}}}
$$

Where:

$$
\begin{aligned}
& \text { E - relative mean error }(\%) ; \\
& M_{i} \text { - values obtained experimentally; } \\
& \mathrm{Mp}_{\mathrm{i}} \text { - values predicted by the model, } \\
& \mathrm{n} \text { - number of experimental data. }
\end{aligned}
$$

The flowability of guava pulp powders at 4 and $8 \%$ albumin was evaluated by analyzing shear stress, apparent density, and wall friction angle. The samples were placed in a Powder Flow Test (PFT) equipment (Brookfield Engineering Laboratories). Based on shear stress, flow index was determined (Equation 3 ) to classify powders in terms of flow, as shown in Table 2 (Jenike, 1964).

$$
\mathrm{I}_{\mathrm{f}}=\frac{\sigma_{1}}{\sigma_{\mathrm{c}}}
$$

Where:

$$
\begin{aligned}
& \mathrm{I}_{\mathrm{f}} \text { - flow index; } \\
& \sigma_{1} \text { - mean major consolidation stress }(\mathrm{kPa}), \\
& \sigma_{\mathrm{c}} \text { - mean unconfined yield stress }(\mathrm{kPa}) .
\end{aligned}
$$

TABLE 2. Classification of flowability for stored solid products by flow index.

\begin{tabular}{cc}
\hline Flow type & Flow Index $\left(\mathrm{I}_{\mathrm{f}}\right)$ \\
\hline Non-flowing & $\mathrm{I}_{\mathrm{f}}<1$ \\
Very cohesive & $1<\mathrm{I}_{\mathrm{f}}<2$ \\
Cohesive & $2<\mathrm{I}_{\mathrm{f}}<4$ \\
Easy flowing & $4<\mathrm{I}_{\mathrm{f}}<10$ \\
Free flowing & $>10$ \\
\hline
\end{tabular}


The powder microstructure was examined by micrographs from a Quanta FEG 450 scanning electron microscope (SEM). In this sense, we evaluated powder samples of pure guava pulp, guava pulp with $4 \%$ $(\mathrm{m} / \mathrm{m})$ albumin, guava pulp with $8 \%(\mathrm{~m} / \mathrm{m})$ albumin, and pure albumin.

\section{RESULTS AND DISCUSSION}

Table 3 shows the adsorption isotherm models fitted to the data on guava pulp powders from foam-mat drying at $4 \%$ and $8 \%$ albumin. The GAB and Henderson models had the best to the experimental data, but the GAB model had the smallest averages. Both models had less than $10 \%$ errors for all temperatures and albumin concentrations. The coefficients of determination $\left(\mathrm{R}^{2}\right)$ were close to $99 \%$. According to Lomauro et al. (1985), mean errors below 10\% are suitable to define models that best fit the proposed studies. In this study, the GAB model had the best fit, with determination coefficients $\left(\mathrm{R}^{2}\right)$ above 0.99 and mean errors (E) below 8\%. Conversely, the Oswin model showed the largest errors, 11.76 and $15.93 \%$ at $35{ }^{\circ} \mathrm{C}$. Cavalcante et al. (2018) obtained similar behavior studying soursop pulp powder, where the GAB model had the best fit and errors below 5\%. Furthermore, Bezerra et al. (2011) reported the GAB and Oswin models as being satisfactory to fit adsorption isotherm data of powdered mango, with a determination coefficient of 0.96 and relative mean errors (E) below 10\%.

TABLE 3. Results of adsorption isotherms for guava pulp powders from foam-mat drying.

\begin{tabular}{|c|c|c|c|c|c|}
\hline \multirow{2}{*}{ Model } & \multirow{2}{*}{ Parameter } & \multicolumn{2}{|c|}{$4 \%$ albumin } & \multicolumn{2}{|c|}{$8 \%$ albumin } \\
\hline & & $35^{\circ} \mathrm{C}$ & $45^{\circ} \mathrm{C}$ & $35^{\circ} \mathrm{C}$ & $45^{\circ} \mathrm{C}$ \\
\hline \multirow{5}{*}{ GAB } & $\mathrm{X}_{\mathrm{m}}$ & 0.1172 & 0.1607 & 0.1821 & 0.2143 \\
\hline & $\mathrm{C}$ & 0.9663 & 0.5939 & 0.7119 & 0.4598 \\
\hline & $\mathrm{K}$ & 0.8637 & 0.8933 & 0.7754 & 0.8288 \\
\hline & $\mathrm{R}^{2}$ & 0.996 & 0.995 & 0.993 & 0.997 \\
\hline & E (\%) & 6.45 & 7.64 & 7.73 & 6.31 \\
\hline \multirow{5}{*}{ BET } & $\mathrm{X}_{\mathrm{m}}$ & 0.3808 & 0.5071 & 0.4824 & 0.5411 \\
\hline & $\mathrm{C}$ & 0.1308 & 0.1075 & 0.1200 & 0.09992 \\
\hline & $\mathrm{n}$ & 5.32 & 5.55 & 4.42 & 4.98 \\
\hline & $\mathrm{R}^{2}$ & 0.987 & 0.994 & 0.987 & 0.993 \\
\hline & E (\%) & 10.05 & 8.43 & 8.41 & 8.97 \\
\hline \multirow{4}{*}{ Henderson } & $\mathrm{a}$ & 0.7774 & 0.6665 & 0.8440 & 0.7036 \\
\hline & $\mathrm{b}$ & 4.61 & 3.35 & 5.11 & 3.75 \\
\hline & $\mathrm{R}^{2}$ & 0.996 & 0.994 & 0.993 & 0.995 \\
\hline & E $(\%)$ & 4.93 & 9.38 & 8.16 & 7.89 \\
\hline \multirow{4}{*}{ Oswin } & $\mathrm{a}$ & 0.09039 & 0.09472 & 0.09587 & 0.09081 \\
\hline & $\mathrm{b}$ & 0.7288 & 0.9349 & 0.6763 & 0.8916 \\
\hline & $\mathrm{R}^{2}$ & 0.991 & 0.992 & 0.983 & 0.995 \\
\hline & E $(\%)$ & 11.76 & 7.01 & 15.93 & 5.45 \\
\hline
\end{tabular}

Description of parameters: $\mathrm{X}_{\mathrm{m}}$ - molecular monolayer moisture content ( $\mathrm{g}$ water per g dry solid, $\mathrm{db}$ ); $\mathrm{R}^{2}$ - coefficient of determination; $\mathrm{E}$ (\%) mean relative error; $\mathrm{C}, \mathrm{K}$ - molecular sorption constants; $\mathrm{n}$ - number of molecular layers; $\mathrm{a}, \mathrm{b}$ - model fit constants.

When analyzing the behavior of lyophilized mango pulp powder, Moreira et al. (2013) reported that the GAB model showed the best fit to the experimental data, in which isotherms had type III format, mean errors (E) between 4.09 and $5.18 \%$, and determination coefficients $\left(\mathrm{R}^{2}\right)$ of 0.99 , similar to the results of our study.

The constant $\mathrm{K}$ values in the GAB model were less than 1.0 (Table 3), which is suitable for the said model. According to Timmermann (2003), values greater than 1.0 are unsuitable for indicating infinite sorption. Monolayer moisture estimates $\left(\mathrm{X}_{\mathrm{m}}\right)$ from the $\mathrm{GAB}$ model are relevant since the deterioration of food products is minor when they are stored at moisture contents below those of the monolayer $\left(\mathrm{X}_{\mathrm{m}}\right)$. Deterioration reaction rates, mainly in dehydrated food, are minimal if below that value except for oxidation of unsaturated fats (Celestino, 2010).

Table 3 shows that the rise in temperature from 35 to $45{ }^{\circ} \mathrm{C}$ increased molecular monolayer moisture content $\left(\mathrm{X}_{\mathrm{m}}\right)$ and constant $\mathrm{K}$ values in the GAB model at the studied albumin concentrations. Moreira et al. (2013) and Pena et al. (2010) found similar behavior when studying adsorption isotherms, the first for lyophilized mango and the latter for 
acai powder. Moreira et al. (2013) commented that increases in monolayer moisture content $\left(\mathrm{X}_{\mathrm{m}}\right)$ due to temperature elevation is unusual for all food types. Temperature rises may change the structure of food products, releasing active sites with an affinity for water molecules; or rises in solute solubility (sugars), an increasing number of water molecules retained in the monolayer (Ferreira \& Pena, 2003). Therefore, increasing temperatures of guava pulp powders enhance the solubility of sugars present, and hence in $\mathrm{X}_{\mathrm{m}}$ values. $\mathrm{X}_{\mathrm{m}}$ values were higher in powdered guava pulp with $8 \%$ albumin compared to $4 \%$; this is because albumin binds to water more easily, thus retaining more water molecules.

The C-constant values of the GAB and BET models (Table 3) increased with reducing temperatures. This is

A.

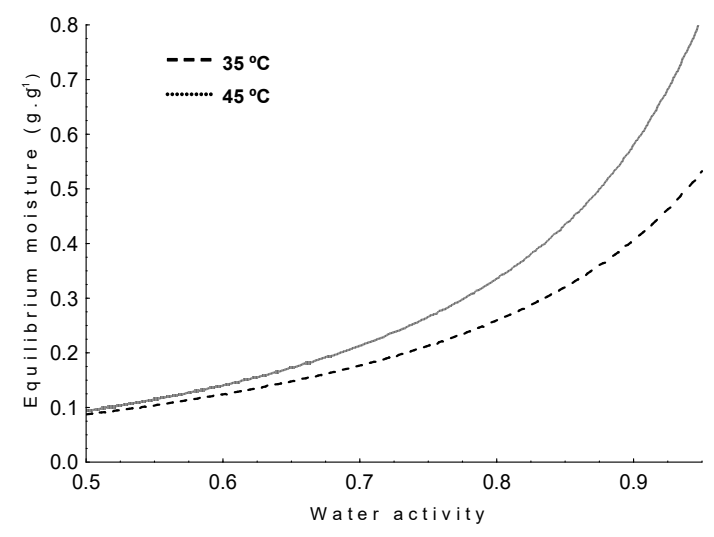

FIGURE 1. Adsorption isotherms of guava pulp powders at $4 \%(\mathrm{~A})$ and $8 \%(\mathrm{~B})$ albumin $(\mathrm{m} / \mathrm{m})$ fitted by the GAB model at 35 and $45^{\circ} \mathrm{C}$.

Figure 1 shows that the equilibrium moisture increases with increasing temperatures for the same water activity value, that is, guava pulp powder becomes more hygroscopic. This behavior can be explained because temperature affects the mobility of water molecules and the equilibrium between vapor and adsorbed phases. In general, temperature rises lead to reductions in equilibrium moisture. This can be attributed to physical and/or chemical changes that reduce active sites available for the binding of water

A.

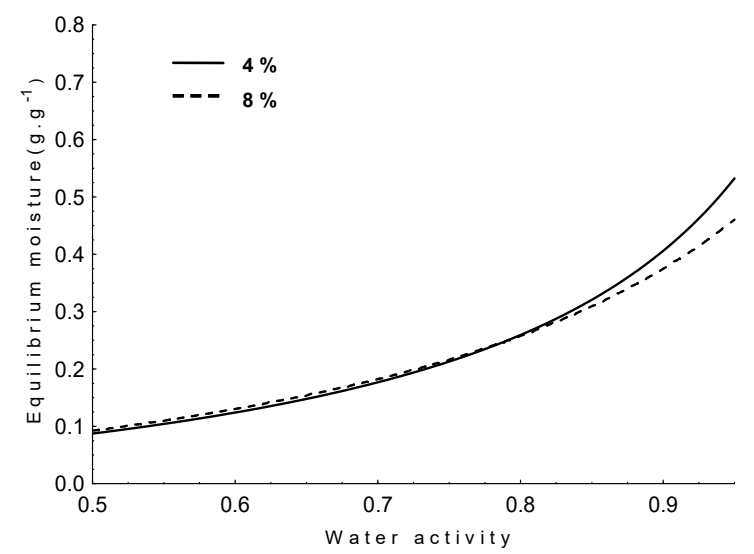

expected since a drop in temperature favors the interaction stress between adsorbent and adsorbate (Gabas et al., 2007).

Given its low errors, the GAB model was chosen to represent the adsorption isotherms of guava pulp powders. Figure 1 shows the curves of adsorption isotherms for guava pulp powders at $4 \%$ and $8 \%$ albumin. Both powders showed an increase in water activity with an increase in equilibrium moisture (content) at a certain temperature. The curves showed a type III isotherm pattern according to the IUPAC (1985). Moreover, according to Moreira et al. (2013), such behavior is characteristic of foods rich in soluble components such as sugars. High-sugar foods exhibit isotherms in which little water activity linearly increases equilibrium moisture content, but great water activity increases it rapidly (Pedro et al., 2010).

B.

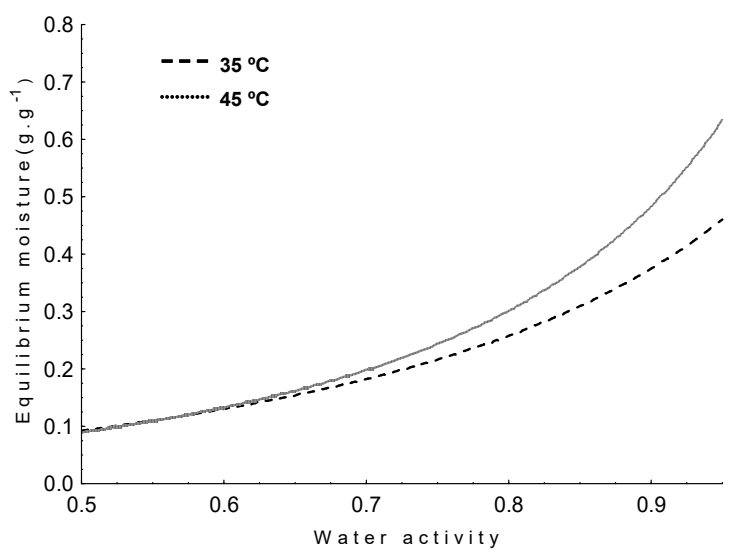

molecules (Goula et al., 2008; Moreira et al., 2013). But in some food types (as in this study), the rises in temperature also increase the solubility of sugars present, thus increasing equilibrium moisture (Ferreira \& Pena, 2003). Ribeiro et al. (2016) found similar behavior in analyzing isotherms of acerola pulp powder.

Figure 2 shows the effect of albumin concentrations (4\% and $8 \%$ ) on adsorption isotherms of guava pulp powders at 35 and $45^{\circ} \mathrm{C}$.

B.

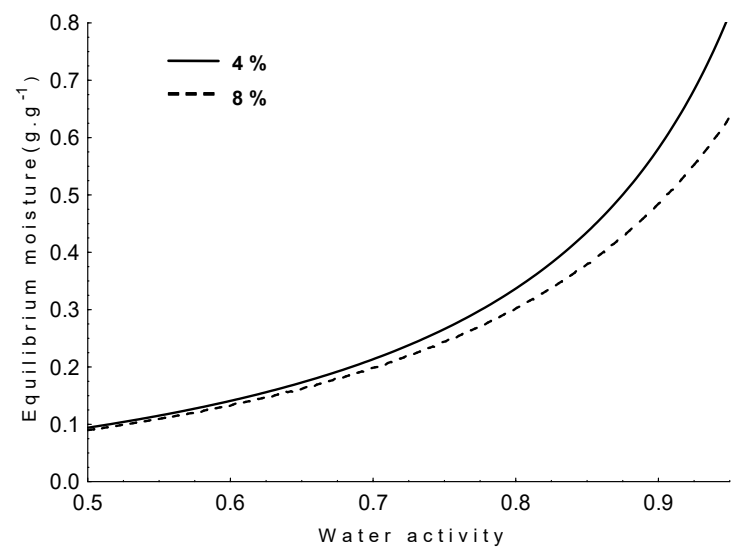

FIGURE 2. Adsorption isotherms of guava pulp powders at $4 \%$ and $8 \%$ albumin obtained by foam-mat method at 35 (A) and 45 ${ }^{\circ} \mathrm{C}(\mathrm{B})$, predicted by the GAB model. 
Figure 2A shows a very similar behavior between the two isotherms until water activity approaches 0.8 . For water activities above 0.8 , the powder containing $8 \%$ albumin showed lower equilibrium moisture than that of powder with $4 \%$. An inverse behavior was also verified by TelisRomero et al. (2005) and Ribeiro et al. (2016) for water activities above 0.7 . Telis-Romero et al. (2005) explained that such behavior inversion in isotherms of high-sugar products can be due to an increased sugar solubility in water. This behavior may have contributed to the inversion observed in Figure 2A with increased water activity since the powder containing $4 \%$ albumin has a greater amount of sugars proportionally. At $45{ }^{\circ} \mathrm{C}$ (Figure 2B), the isotherm of powder containing $8 \%$ albumin was more stable throughout the water activity range, evidencing the high-temperature effect in the presence of albumin and sugars.

Flow index $\left(\mathrm{I}_{\mathrm{f}}\right)$ was calculated (Eq. 1) based on shear stress means (Table 4 ). The $\mathrm{I}_{\mathrm{f}}$ values for guava pulp powders at $4 \%$ and $8 \%$ albumin were 8.00 and 8.68 , respectively. These values are between 4 and 10, which, according to Jenike (1964), are classified as easy flowing powders (Table 2).

TABLE 4. Shear stresses for guava pulp powder at albumin concentrations of $4 \%$ and $8 \%$.

\begin{tabular}{cccc}
\hline & 4\% albumin & \multicolumn{2}{c}{$8 \%$ albumin } \\
\hline$\sigma_{1}(\mathrm{kPa})$ & $\sigma_{\mathrm{c}}(\mathrm{kPa})$ & $\sigma_{1}(\mathrm{kPa})$ & $\sigma_{\mathrm{c}}(\mathrm{kPa})$ \\
\hline 1.587 & 0.309 & 1.937 & 0.322 \\
3.429 & 0.436 & 4.461 & 0.498 \\
7.301 & 0.770 & 9.232 & 1.145 \\
15.339 & 1.825 & 19.594 & 1.965 \\
30.717 & 3.954 & 38.956 & 4.621 \\
\hline
\end{tabular}

$\sigma_{1-}$ major principal consolidation stress; $\sigma_{\mathrm{c}}$ - unconfined yield stress.

Shear stress results can also be evaluated graphically (Figure 3). Lopes Neto et al. (2009a) reported that the closer the straight line resulting from linear stress fit to the horizontal axis, the greater the tendency of products to flow easily; moreover, the closer it is to the vertical axis, the greater the flow resistance. The linear fits for powders containing $4 \%$ and $8 \%$ albumin indicated a similar behavior between one another, with similar angular coefficients and following $\mathrm{I}_{\mathrm{f}}$ values.

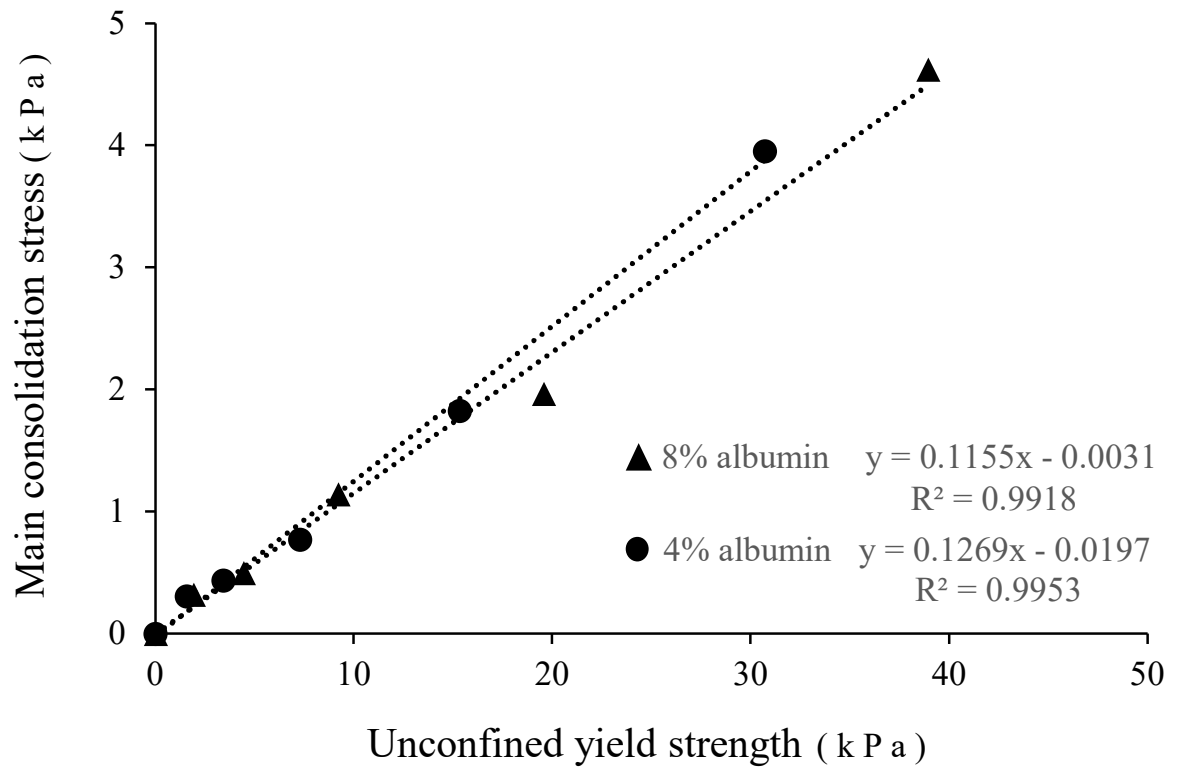

FIGURE 3. Main consolidation stress and unconfined yield stress for guava pulp powders obtained by foam-mat drying at 4 and $8 \%$ albumin.

Table 5 presents the values for the densities and the wall friction angles of the guava pulp powders obtained by consolidation stress application. The increase in the consolidation stress applied to the powders caused them to compact with a consequent increase in their density. This behavior is similar to the results found by Campos \& Ferreira (2013). The increase in density with increasing albumin concentration can be attributed to changes in particle shape, roughness, cohesion and agglomeration (Mallol et al., 2008; Mohammed et al., 2011). 
TABLE 5. Flow properties of guava pulp powders obtained by foam-mat drying at 4 and $8 \%$ albumin.

\begin{tabular}{ccccc}
\hline Albumin concentration & \multicolumn{2}{c}{$\rho\left(\mathrm{kg} / \mathrm{m}^{3}\right)$} & \multicolumn{2}{c}{$\varphi\left({ }^{\circ}\right)$} \\
\cline { 2 - 5 }$(\%)$ & higher & lower & higher & lower \\
\hline 4 & 653.8 & 401.7 & 21.9 & 15.7 \\
8 & 688.9 & 445.4 & 20.4 & 13.6 \\
\hline
\end{tabular}

$\rho$ - powder density; $\varphi$ - wall friction angle (stainless steel).

Campos \& Ferreira (2013) correlated powder density changes during stress application with powder cohesion; they observed that higher density changes increased powder cohesion. Here we noted that the powder containing $4 \%$ albumin showed higher density changes (Table 5 ).

Regarding wall friction angle (Table 5), the powder containing $8 \%$ albumin had higher values compared to those of $4 \%$ albumin powder. Lopes Neto et al. (2009b) found values between $10.4^{\circ}$ and $13.2^{\circ}$ for wheat flour and between $8.7^{\circ}$ and $11.5^{\circ}$ for corn flour. Fitzpatrick et al. (2004) stated that a wall-friction angle stands for the adhesive strength between a powdered product and the material of the wall of the storage environment, and the higher the angle, the harder the powder flow along that wall. In this sense, the lower the angle, the less sloped the wall to ensure powder flow. Regarding mean wall-friction angle, powders containing

A.

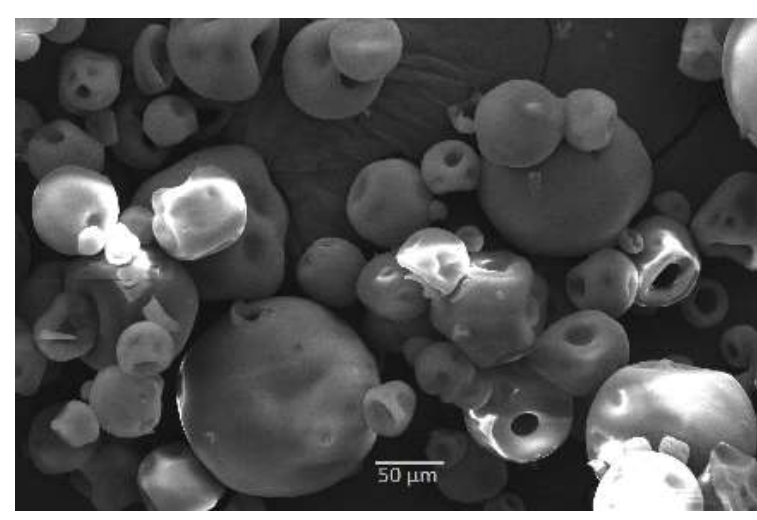

C.

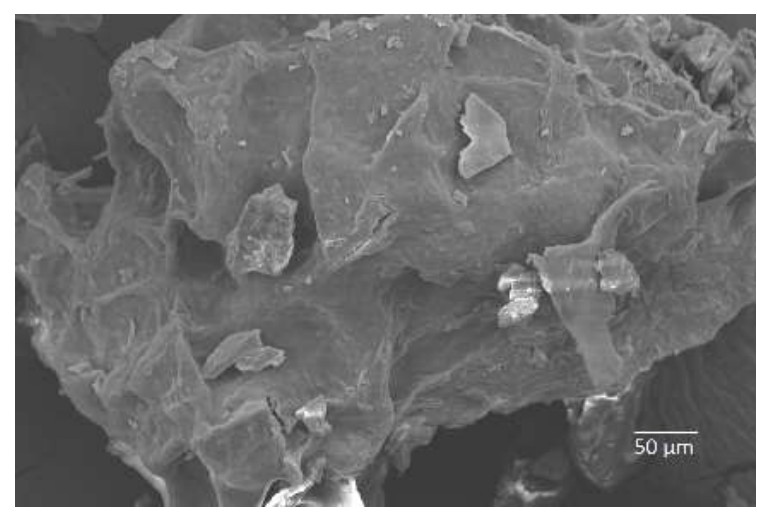

$8 \%$ and $4 \%$ albumin showed values of 17 and $18.8^{\circ}$, respectively. Campos \& Ferreira (2013) obtained mean values of 28 and $29^{\circ}$ for alumina powder and ceramic powder, respectively.

According to the micrographs in Figure 4A, albumin has a round granule shape with holes and a smooth surface, probably due to the drying process. These holes help incorporate air during the foaming process. Unlike the albumin-containing powders (Figures 4C and 4D), guava pulp powder without albumin had predominantly rough surface (Figure 4B). Figure 4 shows that albumin addition to the formulations reduced particle surface roughness. For Tonon et al. (2009), smoother surfaces improve the flowability of materials. Furthermore, Udomkun et al. (2015) observed that changes in particle structure may influence water sorption behavior in materials.

B.

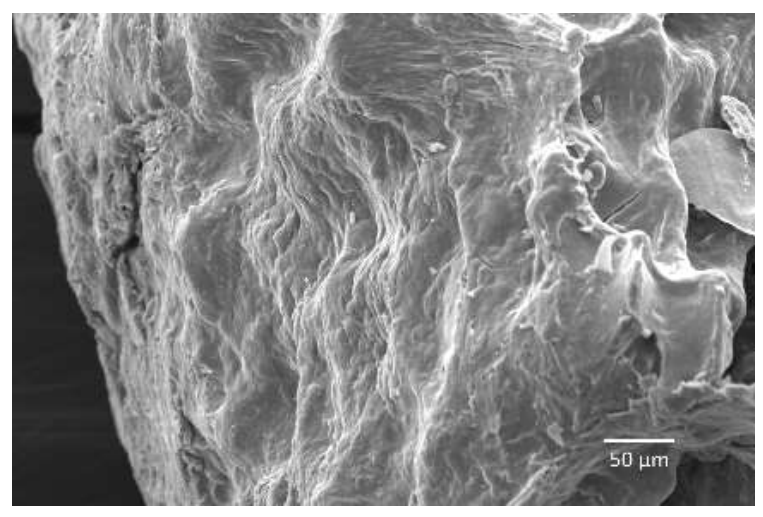

D.

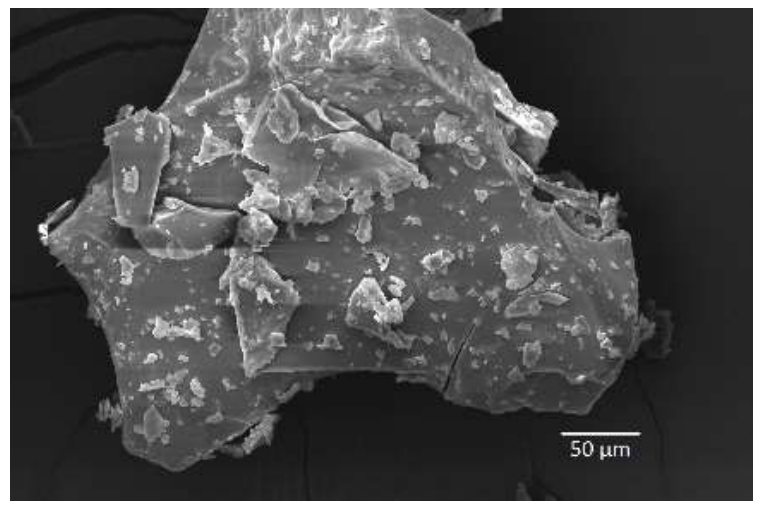

FIGURE 4. Electron micrographs (5000x) of powdered albumin (A), guava pulp powder (B), guava pulp powder containing 4\% (C) albumin $(\mathrm{m} / \mathrm{m})$, and guava pulp powder containing $8 \%(D)$ albumin $(\mathrm{m} / \mathrm{m})$. 


\section{CONCLUSIONS}

1. The isotherms of guava pulp powders were wellfitted by the GAB model and classified as type III. And the presence of albumin increased hygroscopic stability.

2. Albumin-added guava pulp powders were classified as easy flowing. Powder added by $8 \%$ albumin had lower wall friction angles, higher densities, and easier flowing compared to those with $4 \%$ albumin.

3. The micrographs revealed that guava pulp powders obtained by foam-mat drying have particles with a rough surface, and albumin addition reduces it.

\section{REFERENCES}

Bezerra TS, Costa JMC, Afonso MRA, Clemente GAM (2011) Avaliação físico-química e aplicação de modelos matemáticos na predição do comportamento de polpas de manga desidratadas em pó. Revista Ceres 58(3):278-283.

Brito JG, Silva EFM, Costa TL, Rocha APT, Silva OS (2012) Propriedades físicas do cominho em pó comercializado nas feiras livres da Paraíba. Revista Verde 7(1):206-211.

Campos MM, Ferreira MC (2013) A comparative analysis of the flow properties between two alumina-based dry powders. Advances in Materials Science and Engineering 2013(1):1-8.

Celestino SMC (2010) Princípios de secagem de alimentos. Planaltina, Embrapa Cerrados, 51p.

Cavalcante CEB, Rodrigues S, Afonso MRA, Costa JMC (2018) Comportamento higroscópico da polpa de graviola obtida por secagem em spray dryer. Brazilian Journal of Food Technology 21. DOI: https://doi.org/10.1590/19816723.12117

Ferreira CD, Pena RS (2003) Comportamento higroscópico da farinha de pupunha (Bactris gasipaes). Ciência e Tecnologia de Alimentos 23(2):251-255.

Fitzpatrick JJ, Iqbal T, Delaney C, Twomey T, Keogh MK (2004) Effect of powder properties and storage conditions on the flowability of milk powders with different fat contents. Journal of Food Engineering 64(1):435-444.

Gabas AL, Telis VRN, Sobral PJA, Telis-Romero J (2007) Effect of maltodextrin and arabic gum in water vapor sorption thermodynamic properties of vacuum dried pineapple pulp powder. Journal of Food Engineering 82(1):246-252.

Goula AM, Karapantsios TD, Achilias DS, Adamopoulos KG (2008) Water sorption isotherms and glass transition temperature of spray dried tomato pulp. Journal of Food Engineering 85(1):73-83.

Greenspan L (1977) Humidity fixed points of binary saturated aqueous solutions. Journal of Research of the National Bureau of Standards 81(1):89-96.

Infante J, Selani MM, Toledo NMV, Silveira-Diniz MF, Alencar SM, Spoto MHF (2013) Atividade antioxidante de resíduos agroindustriais de frutas tropicais. Alimentos e Nutrição 24(1):87-91.
IUPAC - International Union of Pure and Applied Chemistry (1985) Reporting Physisorption data for gas solid. systems with special reference to the determination of surface area and porosity. Pure \& Applied Chemistry 57(4):603-619.

Jenike AW (1964) Storage and flow of silos. Salt Lake City. University of Utah. Bulletin 123. Engineering Experiment Station 53(26):1-198.

Kurozawa LE, El-Aouar AA, Murr FEX (2005) Obtenção de isotermas de dessorção de cogumelo in natura e desidratado osmoticamente. Ciência e Tecnologia de Alimentos 25(4):828-834.

Lopes Neto JP, Silva VR, Nascimento JWB (2009a) Propriedades de fluxo de produtos pulverulentos alimentícios. Revista Brasileira de Engenharia Agrícola e Ambiental 13(5):639-644.

Lopes Neto JP, Nascimento JWB, Silva VR (2009b) Efeito do tempo de armazenagem de rações avícolas no dimensionamento de silos. Engenharia Agrícola 29(4):518-527.

Lomauro CJ, Bakshi AS, Labuza TP (1985) Evaluation of food moisture sorption isotherm equations. Part I: Fruit, vegetable and meat products. Lebensmittel- Wissenschaft \& Technologie 18(1):111-117.

Mallol G, Amorós JL, Orts MJ, Llorens D (2008) Densification of monomodal quartz particle beds by tapping. Chemical Engineering Science 63(1):5447-5456.

Mata MERMC, Duarte MEM, Alsemo GCS, Rodrigues E, Guedes MA, Cavalcanti ASRRM, Oliveira CCA (2005) Obtenção de graviola em pó pelo processo de liofilização. Revista Brasileira de Produtos Agroindustriais 7(2):165-172.

Matos ENV, Sampaio RM, Paula ML (2014)

Determinação das isotermas de adsorção e do calor de sorção de farinha de babaçu comercial. Cadernos de Pesquisa 21:1-9. Número especial.

Medeiros ML, Lannes SCS (2010) Propriedades físicas de substitutos do cacau. Ciência e Tecnologia de Alimentos 30(1):243-253.

Mohammed SA, Abdullah EC, Geldart D, Raman AAA (2011) Measuring powder flowability with a modified Warren Spring cohesion tester. Particuology 9(2):148-154.

Moreira TB, Rocha EMFF, Afonso MRA, Costa JMC (2013) Comportamento das isotermas de adsorção do pó da polpa de manga liofilizada. Revista Brasileira de Engenharia Agrícola e Ambiental 17(10):1093-1098.

Park KJB, Park KJ, Cornejo FEP, Fabbro IMD (2008) Considerações termodinâmicas das isotermas. Revista Brasileira de Produtos Agoindustriais 10(1):83-94.

Pedro MAM, Telis-Romero J, Telis VRN (2010) Effect of drying method on the adsorption isotherms and isosteric heat of passion fruit pulp powder. Ciência e Tecnologia de Alimentos 30(1):993-1000.

Pena RS, Mendonça NB, Almeida MDC (2010)

Comportamento higroscópico do açaí em pó. Revista Brasileira de Produtos Agoindustriais 12(2):153-161. 
Ribeiro LC, Afonso MRA, Costa JM (2016) Hygroscopic behavior of lyophilized acerola pulp powder. Revista Brasileira de Engenharia Agrícola e Ambiental 20(3):269-274.

Sagar VR, Kumar R (2014) Effect of drying treatments and storage stability on quality characteristics of bael powder. Journal of food Science and Technology 51(9):2162- 2168.

Silva WP, Aires JEF, Castro DS, Silva CMDPS, Gomes JP (2014) Numerical description of guava osmotic dehydration including shrinkage and variable effective mass diffusivity. Food Science and Technology 59(1):859-866.

Spiess WEL, Wolf W (1987) Critical evaluation of methods to determine moisture sorption isotherms. In: Rockland LB, Beuchat LR. Water activity: theory and applications to food. Marcel Dekker, p215-233.
Telis-Romero J, Kohayakawa MN, Silveira Jr V, Pedro MAM, Gabas AL (2005) Enthalpy-entropy compensation based on isotherms of mango. Ciência e Tecnologia de Alimentos 25(2):297-303.

Timmermann EO (2003) Multilayer sorption parameters: BET or GAB values? Colloids and surfaces A. Physicochemical and Engineering Aspects 220(1):235-260.

Tonon RV, Brabet C, Hubinger MD (2009) Influência da temperatura do ar de secagem e da concentração de agente carreador sobre as propriedades físico-químicas do suco de açaí em pó. Ciência e Tecnologia de Alimentos 29(2):444-450.

Udomkun P, Argyropoulos D, Nagle M, Mahayothee B, Müller J (2015) Sorption behaviour of papayas as affected by compositional and structural alterations from osmotic pretreatment and drying. Journal of Food Engineering 157(1):14-23. 